vertical and a loop for horizontal motion, while the head is a loop for vertical and a node for horizontal

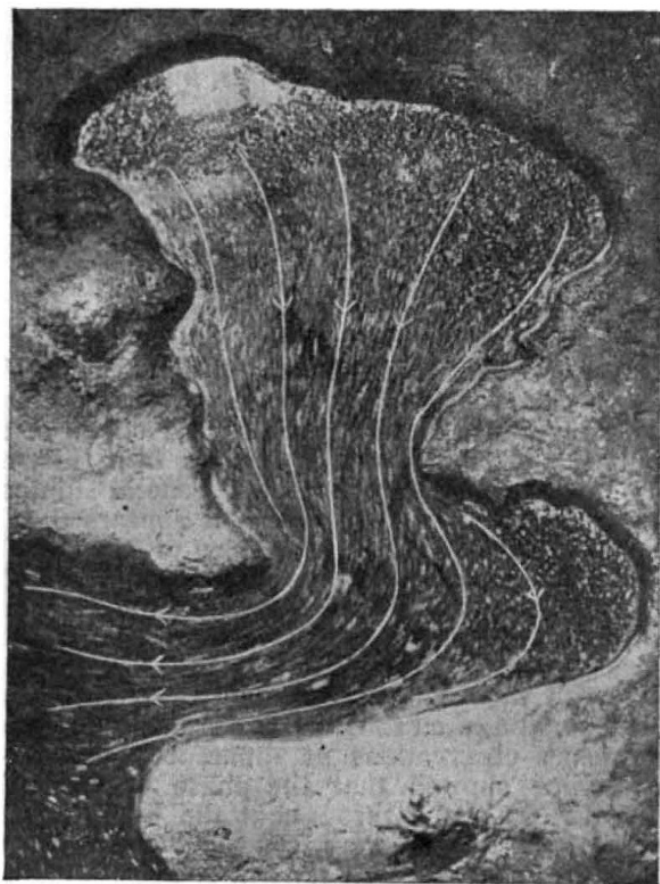

F1G. x.-Model of Aomori Bay, showing stream lines of fundament 1 osci!lation: period $4^{\circ} 453$ in model, $r \in$ presenting $3 \circ 3 \mathrm{~m}$. in the bay itself.

motion. The period of this oscillation in the model was $4^{\circ} 45$ seconds; the factor, corresponding to the scale adopted, being 409o, this represents a period of

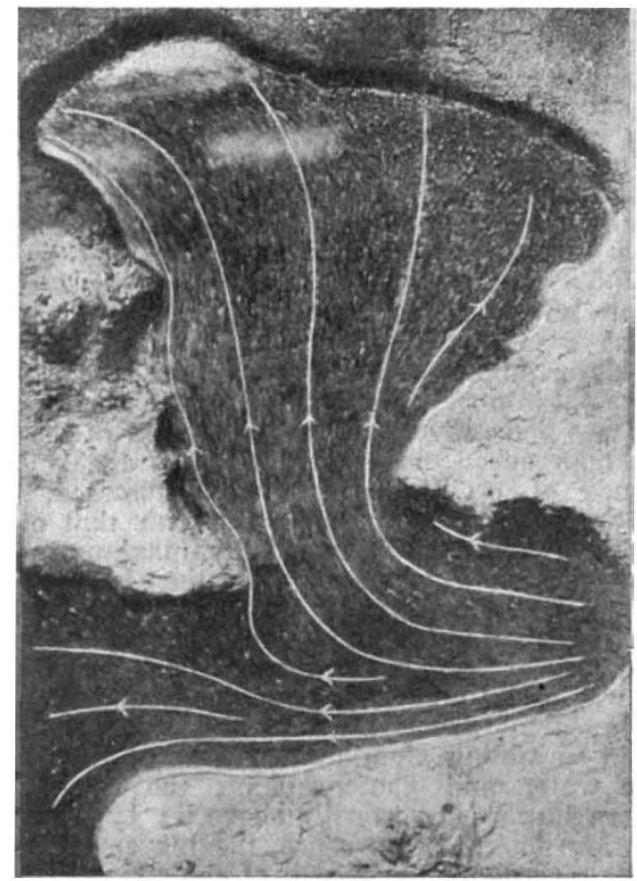

FIG. 2.-Model of Aomori Bay, showing stream lines of lateral oscillation : period $\mathrm{r}^{\circ} 6_{3}$ in model, representing $108 \mathrm{~m}$, in the bay itself.

$303 \mathrm{~m}$. in the actual bay, in which a periodic oscillation of $300 \mathrm{~m}$. was observed. Besides this NO. 2020, VOL. 78] fundamental wave, the water within the bay could be set into lateral oscillation, as shown in Fig. 2, with a period of $I^{*} 60 \mathrm{~s}$. in the model, representing $108 \mathrm{~m}$. in the actual bay, where a well-marked regular undulation of $\mathrm{IO} 3 \mathrm{~m}$. was observed.

The account of the experiments is followed by a mathematical treatment of the subject, and a calcula. tion of the periods of the stationary waves for each of the bays investigated, a calculation which gave results in general, and sometimes in close, accordance with the observed periods. Finally, there is a suggestion that the great increase in the range of tides near the head of large bays may be partly due to this cause. The Bay of Fundy is celebrated for the great range of the tide near its head, where the difference between high and low water is from 50 to to feet, while near the mouth the range is not more than 7 to ro feet; the difference is partly attributable to the banking of the tidal wave as it travels up a narrowing channel, but, the fundamental period of oscillation of the bay being about twelve hours, it is by no means improbable that this has a material effect in increasing the range of the semi-diurnal tide, with which it approximately agrees in period.

We have indicated sufficiently the scope of this important memoir, the unseismological interest of which has been recognised by its simultaneous appearance as one of the publications of the Earthquake Investigation Committee and as a volume of the Journal of the College of Science of Tokyo.

\section{VESTIGES OF SCALES IN THE FOX.}

$\mathrm{N}$ the case of such a familiar animal as the fox 1 it might well have been supposed that everything worth knowing in the matter of its bodily structure had already been recorded. That this is not so is demonstrated in an article by Mr. K. Toldt, of Vienna, published in the April number of the Zoologischer Anzeiger, where it is shown, on what appears to be practically conclusive evidence, that the fox is descended from ancestors the bodies of which appear to have been clothed with horny scales like those of the pangolins, or scaly ant-eaters. Although these scaly ant-eaters are the only living mammals the bodies of which are completely covered with overlapping scales, armadillos furnish us with an example of another type of armour in the same class; while there are several groups of mammals in which some portion of the body is scaly. In the rat, for example, the whole tail is scaled, and more or less distinctly scaled areas are met with in several porcupines and certain other rodents, as well as on the tail of the great South American anteater. In all cases where hairs grow from the body between the scales (as they almost invariably do), such hairs, in place of being scattered about in an irregular manner, have a certain definite arrangement. They grow, for instance, in isolated bundles, arranged in some cases in groups of three or four, and placed at regular intervals from one another.

From the fact that the hairs are arranged in this peculiar and definite fashion in a number of species which show no traces of scales, it has been suggested that such mammals trace their descent from scaleclad ancestors.

Careful examination of the skins of young foxes has enabled Mr. Toldt to announce, not only that the hairs are arranged in this peculiar fashion, namely, in groups of three bundles, each containing some:fourteen or fifteen hairs, but likewise that the skin itself actually exhibits a structure such as would be presented by that of a pangolin after the scales had been pulled out. Viewed'through a microscope, the skin presents, 
in fact, the appearance of a roof covered with overlapping rounded tiles, with the triply-arranged bundles of hair growing between each " tile." Moreover, when seen in cross-section, the skin is observed to be thrown into a series of ridges or steps, each of which represents the free edge of one of the "tiles." To explain such a structure otherwise than as representing the bed of a scaly armour seems impossible, or at all events illogical, and we are accordingly compelled to accept the author's view that the fox is descended from scale-clad ancestors. No actual traces of scales have been observed in any of the skins yet examined, but Dr. Toldt suggests that such might be detected if a large series of skins of young fox-cubs were examined under proper conditions.

Although no mention of this point is made by the author of the paper referred to, the fox is just one of those animals which might naturally be expected to retain traces of its descent from reptilian ancestors. There is good reason to believe that the extinct mammal-like reptiles of South Africa were the immediate forerunners of the primitive carnivora or creodonts of the Tertiary period; while it is certain that from these latter are descended the modern carnivora, among which the fox, in common with the other members of the dog tribe, is one of the most primitive and least specialised representatives.

\section{NOTES.}

A statue to Bunsen, raised by public subscription, will be unveiled at Heidelberg on August I.

WE regret to see the announcement of the death of Lord Blythswood, F.R.S., at seventy-one years of age.

Sir William H. White, K.C.B., F.R.S., has been elected chairman of the council of the Royal Society of Arts for the ensuing year.

Prof. George Hale, director of the Mount Wilson Observatory, California, has been elected a foreign correspondant in the astronomical section of the Paris Academy of Sciences in succession to the late Prof. Asaph Hall.

Dr. Bouchard has been elected president of the Paris Academy of Sciences in succession to M. H. Becquerel, who was recently appointed permanent secretary of the academy. Prof. Emile Picard succeeds Dr. Bouchard as vice-president.

THE congress of meteorologists representative of the United Kingdom and of the British colonies and dependencies, which it was proposed to hold in Quebec in the last week of this month, has been postponed until next year.

THE well-known expert on turbines and hydraulic engineering, Prof. A. Stodola, of the Zürich Polytechnic College, has been awarded the Grashof gold medal of the Society of German Engineers.

THE council of the Society of Engineers and the council of the Civil and Mechanical Engineers' Society have approved a scheme of amalgamation which is expected to meet with the cordial support of the members of both bodies. This is a welcome innovation in the policy of technical societies, as of late years there has been a growing tendency to form new societies, and the consequent overlapping of work has rendered bibliographical research increasingly difficult.

A THOROUGHLY representative exhibition of mining machinery was opened at Olympia by Lord Strathcona on July 11. An interesting popular feature of the exhibition, which will remain open until July $3 \mathrm{I}$, is a series of realistic scenes giving an excellent idea of the practical working side of the Empire's mining industries. These scenes represent prospecting for diamonds in South Africa, gold mining in the Transvaal, alluvial gold mining in the Klondyke, hydraulic gold mining in New Zealand, tin mining, coal mining, granite quarrying, and Bath-stone mining.

In the House of Commons on July 8, Mr. Dundas White asked the Prime Minister whether the Government would give facilities for the passing this session of the Daylight Saving Bill, now entitled the Local Time (Great Britain and Ireland) Bill; and, if so, whether the Government would propose amendments making clear that the adoption of the proposed modification of time was not compulsory, and substituting for the term local time some less ambiguous term. In reply, Mr. Asquith said :--" The Government have no intention of giving facilities for the passing of the Daylight Saving Bill."

IN the Chancery Division of the High Court, Mr. Justice Eve has just decided that china clay is a mineral within the meaning of the Railway Clauses Consolidation Act, I845. The right to work china clay in some land purchased by the Great Western Railway Co. was claimed by the vendor to the company and owner of the adjoining land. Notice of this claim was given to the railway company, which brought the action for an injunction to restrain the owner from excavating the land near and under their line in Cornwall to get china clay, on the ground that the product obtained was not a mineral in the sense of the Act of I845. Mr. Justice Eve, however, decided against this view, and gave judgment for the defendents. A full report of the judgment appears in Wednesday's Times.

Wrтh a view to obtain accurate information regarding the nature and extent of the damage done by rats in the United Kingdom, the committee of the Society for the Destruction of Vermin has prepared a schedule of questions for wide distribution. It is desired to obtain information from all persons who are in a position from their own experience to give particulars concerning temporary or permanent rat plagues, the damage done by rats, the steps taken to prevent such damage, and the results obtained. The secretary of the society, Mr. A. E. Moore, 95 Wigmore Street, London, W., will be glad to send a copy of the schedule of questions to any person who is able and willing to send information.

THE Paris correspondent of the Times announces that M. Henri Deutsch de la Meurthe has offered a new prize of xoool. for the first aërial automobile apparatus, either lighter or heavier than air, which will transport Commandant Renard to England. If he is conveyed by an automobile balloon, the descent must be made at Aldershot Camp. If he goes on an aëroplane, however, it will only be necessary to reach the English coast. From the same source we learn that Commandant Renard, in some comments on the recent exploits of. Mr. Henry Farman at Issy les Moulineaux and of M. Delagrange in Rome, referred to the fact that both aëronauts have remained more than fifteen minutes in the air, and remarked, "In less than two years the distance traversed by an aëroplane has passed from twenty-five metres-the famous preliminary bound of M. Santos Dumont in October, Ig06-to nearly twenty kilometres, a proportion of I to 800 ." At that rate, within two years it will be possible to make journeys of twenty days without stopping. At all events, there is

$$
\text { NO. 2020, VOL. 78] }
$$

